\title{
LEHETốSÉGEK ÉS AKADÁLYOK AZ EGÉSZSÉGES ÉLELMISZER-FOGYASZTÁS TERÜLETÉN
}

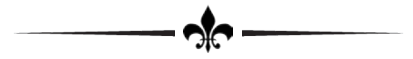

\section{OPPORTUNITIES AND OBSTACLES IN THE HEALTHY FOOD CONSUMPTION AREA}

\author{
$-2$ \\ MIHÁLY, Nikolett \\ RóNAI, Ramóna \\ KoMÁROMI, Nándor \\ LEHOTA, József
}

Szent István Egyetem, Gazdaság- és Társadalomtudományi Kar, Üzleti Tudományok Intézete

(Szent István University, Faculty of Economics ans Social Sciences, Business Studies Institute)

H-2100 Gödöllő, Páter Károly út 1.

e-mail: mihaly.nikolett@gtk.szie.hu

\begin{abstract}
S1
The issue of healthy food consumption is an extremely hot topic in today's fast-paced world. One of today's ruler trends are the health awareness and health market expansion. The role of the health of consumers is appreciated. People spend more and more to preserve their health. The consequence of conscious consumption is that individuals can keep their physical and mental activity for a longer time remaining their life and accordingly they can be involved in the economic growth. Our central hypotheses were that the financial situation, the level of consciousness and „identity" have a decisive influence on women who assume a healthy eating habit in Hungary. We also presumed a link between health consciousness and financial attitudes, as well as a positive relationship between health consciousness and behavioral intent and normative beliefs. Our results confirm: the income status and the degree of awareness mostly influence the existence of a healthy diet.
\end{abstract}

KuLCSSZAVAK: fogyasztás, egészség, háztartás, menedzsment

JEL-KódoK (JEL CODES): E21, H31, H51

DOI: https://doi.org/10.20494/TM/5/1/5

\section{BEVEZETÉS - INTRODUCTION}

A tudáson alapuló és egészséges fogyasztás kérdése rendkívül aktuális téma; napjaink egyik uralkodónak számító megatrendje az egészségtudatosság, a kapcsolódó piacok terjeszkedése. A fogyasztók számára felértékelődött az egészség szerepe, egyre többet költünk annak megőrzésére (TÖRÖCSIK, 2011). Akik komolyan törődnek magukkal, és odafigyelnek, hogy
KEYWORDS: consumption, health, household, management

megelőzzék a betegségeket, kisebb eséllyel lesznek betegek, illetve hamar felismerik a tüneteket, ebből adódóan hamarabb meggyógyulnak. A megelőzésnek fontos szerepe van abban, hogy az egyén tovább lehet aktív, így tovább tud szerepet vállalni a gazdasági növekedésben (RÓNA et al., 2010). Az élelmiszervásárlás során mind jelentősebb hangsúlyt kap, hogy az étel miként hat a szervezetünkre. Az egészségi állapotunk minőségében több tényező együttes hatása érvényesül; ezek közül a legfontosabb a 
fizikai állapot, a mentális állapot, a pénzügyi helyzet valamint a szellemi állapot. Tanulmányunkban, ezeket a tényezőket vesszük górcsó alá, kapcsolódó empirikus kutatásunkban pedig elsősorban arra kerestük a választ, hogy az egészségtudatosság, ezen belül az egészséges táplálkozás milyen tényezők függvénye. Központi hipotézisünk volt, hogy Magyarországon, a nők esetében az anyagi helyzet, a tudatosság szintje, valamint az „identitás” döntő módon befolyásolja az egészséges táplálkozáson alapuló életmódot. Az egészségtudatosság és a pénzügyi attitűd között is vélelmeztünk öszszefüggést, valamint az egészségtudatosság, a viselkedési szándék és a normatív hiedelmek között is pozitív kapcsolatot feltételeztünk.

\section{KAPCSOLÓdó KUTATÁSI EREDMÉNYEK - SOME RELEVANT RESEARCH RESULTS}

Az ELEF (Európai Lakossági Egészségfelmérés, 2009) négy eltérő egészségmagatartás típust állapít meg. Ezek a következők: passzív egészségtudatos, hiányosan egészségtudatos, kevéssé egészségtudatos, valamint egészségtudatos típus. Az egészségtudatos csoportba sorolhatók, akik élnek az egészségügyi rendszer nyújtotta lehetőségekkel, fontos számukra az egészségük megőrzése, kiegyensúlyozott étkezést folytatnak, nem fogyasztanak alkoholt, nem dohányoznak, nem utasítják el az alternatív gyógymódokat, és a táplálék-kiegészítők rendszeres fogyasztói (KSH, 2010). A Millward Brown Healthcare és a TGI (Target Group Index) 2010-ben készített kutatást a 18-69 év közötti lakosság bevonásával a magyar lakosság egészségtudatosságáról, melynek fóbb eredményei szerint a magyar lakosság prevenciós szemlélete még nem fejlődött ki, hiszen még mindig csak akkor törődünk az egészségünkkel, ha már „vészhelyzet” áll fenn. A felnőtt lakosság kb. 50\%-a úgy érzi, hogy nem szükséges többet tenni az egészségének megőrzése érdekében. A lakosság további részéról is elmondható, hogy kerüli az orvosokkal való találkozást (52\%), továbbá a gyógyszerszedést (38\%). A megkérdezettek fele tartja magát pozitív szemléletűnek, amikor az egészsége kerül szóba; ezek a meg- kérdezettek úgy vélekednek, hogy saját maguk tudatosan képesek formálni egészségi állapotukat. A valós prevenciós szemlélet és gyakorlat még gyerekcipóben jár, vagy egyáltalán nem létezik, és a teljes lakosság csak egy kis szegmensének mindennapjaiban jelenik meg. A felnőtt lakosság kevesebb, mint 20\%-a ismeri csak a komplex egészségmegőrző technikákat, de esetükben sem beszélhetünk szakmailag megalapozott prevenciós gyakorlattal. Leginkább a nőket, a városban élőket, és a magas státusszal rendelkezőket jellemzi ez a szemlélet. A tanulmányból tehát világossá válik, hogy a magyar társadalomnak még alacsony szintű az egészségtudatossága, de már kialakultak azok a csoportok, akik megfelelő informáltság és felvilágosítás mellett, hosszú távon tudatos fogyasztókká válhatnak (MEDICALONLINE, 2010). 2013-ban a Szinapszis Kft. a magyar lakosság egészségtudatosságát az orvosok véleménye alapján vizsgálta, és hasonló eredmények születtek (SZINAPSZIS, 2013).

SZABÓ (2016) meglátása szerint az egészségmagatartás összefüggéseit legjobban az alábbiakban bemutatott modell alapján lehet szemléltetni (1. ábra).

Az elmélet szerint az attitűd, az észlelt normák és a személyes hatóerő érzete alapfeltétel ahhoz, hogy a viselkedés megvalósuljon. Ezen túl a személynek megfelelő tudással és képességekkel is kell bírnia, fel kell ismernie a viselkedési formákat, fontos az is hogy a környezeti feltételek is megfelelőek legyenek, ne legyen akadály, és hogy rendszeresen végezze az adott személy a cselekvést. SZABÓ (2016) meglátása szerint, ez a modell a legalkalmasabb a fogyasztók egészségmagatartásának felmérésére. Kutatásunkban az „attitűd”, azon belül is a „tapasztalati attitűd” kérdéskörből, a „viselkedési szándék” témakörből, az „észlelt normán” belül a leíró és a rendelkező normában szereplő állításokból, illetve a „norma fontosságára” vonatkozóan használtuk fel a kapcsolódó elemeket.

$\mathrm{Az}$ „egészséges táplálkozás” témában RODLER (2004:6) megfogalmazását vettük alapul, azaz: „Az Egészséges Táplálkozás Háza a gabonafélékre épül, a zöldség- és főzelékfélék, illetve gyümölcsök alkotják az oldalfalakat, a tető húsokból és húskészítményekből, valamint tejből és tejtermékekből áll. Ezekből az élelmiszercsoportokból naponta többször 
is kell fogyasztani. Azok a táplálékok, amelyek zsiradékban és cukorban nagyon gazdagok, nem szerepelnek a mindennapi táplálkozás házának szerkezetében, ezeket inkább hetente vagy még annál is ritkábban célszerü fogyasz- tani”. A szakirodalomban megtalálhatóak bizonyos alapelvek, melyek iránymutatást adnak az egészséges táplálkozáshoz. DUDÁS (1998) az 1. táblázatban kitűnően foglalja össze ezeket.

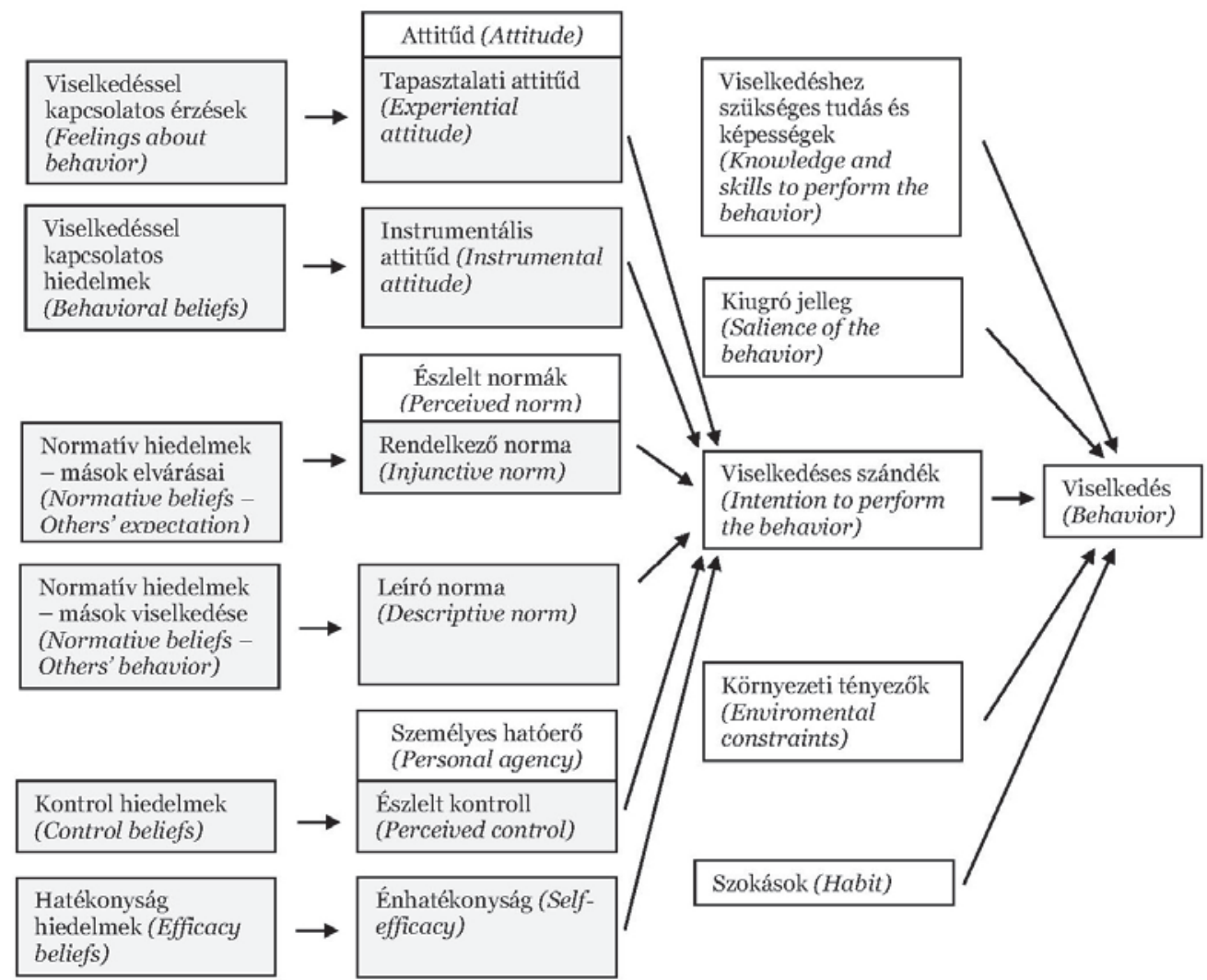

\section{1. ÁBRA}

Az Integrált Viselkedési Modell (IBM) (The Integrated Behavior Model (IBM)

FIG. 1

Forrás (Source): MONTANO és KASPERZYK (2008), illetve SZABÓ (2016) alapján saját szerkesztés (Based on own edition of MONTANO and KASPERZYK (20O8), and SZABÓ (2016)) 


\section{TÁBLÁŻT}

TABLE 1

\section{Összefoglaló táblázat az élelmiszerekről táplálkozás-élettani értéküik szerint, az egészséges étrend alapján (Summary Table of Foods According to Their Nutrition and Physiological Value Based on a Healthy Diet)}

\section{Legegészségesebb élelmiszerek (Healthiest foods) \\ Egészségesnek mondható élelmiszerek (Healthy foods) \\ Friss gyümölcs, zöldség, főzelékfélék (Fresh fruits, vegetables, legumes) \\ Mélyhútött gyümölcs, pasztörizált gyümölcskoncentrátum - cukor nélkül (Frozen fruit, pasteurized fruit concentrate - without sugar)}

Kevésbé ajánlható, ritkán fogyasztandó élelmiszerek (Less recommended, rarely consumable foods)

Dió, mandula, magvak, olajos magvak Szárított gyümölcs, mélyhütött zöld(Walnuts, almonds, seeds, oil seeds)

Mélyhütött gyümölcs cukrozva (Frozen fruit with sugar)

Gyümölcslevek, gyümölcskoncentrátumok pasztörizálva, zöldségkonzerfrozen vegetables, lean vegetables) vek (Fruit juices, pasteurized fruit concentrates, canned vegetables)

Egész gabonaszemek, egész barnarizs, teljes gabonadara, teljes gabonaszemból készült liszt (Whole grain cereals, whole brown rice, whole grain, whole grain flour)

Nyers tej, nyers tejfölből készült aludt-

tej (Raw milk, raw milk sour milk)

Egész gabonából készült pelyhek, kenyér, péksütemények (Whole grain flakes, bread, pastry)

Zoldséglevek (pasztörizált - adaléko nélkül) (Vegetable juices - without pasteurized additives)

Finom lisztből készült péksütemények és kenyér (Delicious bread flakes and bread)
Hidegen préselt, kezeletlen növényi olajok (Cold pressed, untreated vegetable oils)
Pasztörizált friss tej (Pastry fresh milk)
Főzősajt, olvasztott sajt, sajtkonzervek, húskonzervek, halkonzervek (Cheese, frozen cheese, canned foods, canned meat, canned fishes)

Kivont és tisztított növényi olajok, zsírok, margarinok, hidratált és/vagy átészterezett zsírnyersanyagokkal (Extracted and purified vegetable oils, fats, margarines, hydrated and/ or transesterified fatty substances)

Nagy mennyiségű cukor vagy cukor helyettesítőt tartalmazó élelmiszerek (befőttek, édességek)

(Foods containing large quantities of sugar or sugar substitutes confectionery, sweetness)
Sajt, tojás (Cheese, eggs)
Szójabab, szójadara, szójapehely (Soybeans, soymeal, soyflakes)
Hidegen préselt, kezeletlen növényi olaj vagy hidratálás és/vagy észterezés nélküli zsírnyersanyag tartalmú növényi zsírok és margarinok (Cold pressed, untreated vegetable oil or vegetable fats and margarines containing fatty substances with no hydration and/or without esterification)

Friss hús, hal, friss tengeri állatok

(Fresh meat, fish, fresh sea animals)

Méz (nem hőkezelt) (Honey (not

heat-treated))

Forrás (Source): DUDÁS (1998), illetve LAJOS (2005:28) alapján (Based on DUDÁS (1998), and LAJOS (2005:28) 
Lényegében ezekkel az elemekkel és arányokkal rokon egy nemzetközi szinten elfogadott harvardi kutatócsoport által tett táplálkozási ajánlás is, melyet egy piramis segítségével szemléltetnek (WALTER és SKERRETT, 2005). Ezt a piramist használtuk fel a kutatásunkban mi is az egészséges táplálkozás összetevőinek és arányainak szemléltetésére.

A hazai férfiak és a nők élelmiszer-fogyasztását vizsgálva, az alábbiakat állapították meg egy 2014-es kutatásban: A férfiaknak egy harmadával magasabb a kenyér és péksütemény fogyasztásuk, és közel kétszerese a felvágott és tojásfogyasztásuk, a nőkével szemben. A müzli és vegetáriánus ételfogyasztás esetén azonban a nők fogyasztása nagyobb, ezen élelmiszerekből kétszer annyit fogyasztanak, mint a férfiak. Ugyancsak vizsgálták a gyümölcs, zöldség illetve kávé és tea fogyasztást is. Az eredmények azt mutatják, hogy a nők 20\%-kal több kávét és teát, valamint $35 \%$-kal több zöldséget fogyasztanak, mint a férfiak. A húsfogyasztás szempontjából nagyobb fogyasztók a férfiak, ők 10\%-kal több húst fogyasztanak, mint a nők (VETÓNÉ MÓZNER, 2014:61). Az Országos Táplálkozás és Tápláltsági Állapot Vizsgálat (OTÁP) 2014 reprezentatív adatai szerint a hazai felnőttek táplálkozása nagyban eltér a nemzetközi ajánlásoktól. A kutatásból egyértelmüen kiderül, hogy a felnőttek tápanyag beviteli értékei a kedvezőtlen táplálkozási szokásokra vezethetők vissza. Az állati eredetü zsiradékok, a húsok, húskészítmények rendszeres fogyasztói túlzott mértékben, míg a zöldségek, gyümölcsök, a tej és tejtermékek valamint a gabonafélék, különösen a teljes kiőrlésű gabonákból készült élelmiszerek igen alacsony fogyasztása jellemző a felnőttekre (OGYÉI, 2014). Az étel választás két szélsőséges pontja a tisztán tudatosság, és a tisztán élvezet által kiváltott döntés. Mindezt befolyásolja egy adott háztartás felszereltsége, technikai lehetőségei, infrastruktúrája, a választott alapanyagok, a döntéshozó és a felhasználó tudásának szintje. Feltételezésük szerint Magyarországon csak egy szúk réteg teheti meg, hogy tudásának és tájékozottságának megfelelően táplálkozzon.

A pénzügyi attitűd jelentősége. A tudatos fogyasztásnak mind nagyobb szerepe van napjainkban. Bár az irodalmi áttekintés során kapcsolódó kutatást nem találtunk, de véleke- désünk szerint, a tudatos és sikeres pénzkezelés, valamint az egészségtudatos attitűd szoros kapcsolatban áll egymással, hiszen mindkettő a belátáson alapuló, racionális jóléti törekvéseket tükrözi - tehát egyfajta generalizációról beszélhetünk. Ahhoz, hogy a mindennapokban egészségesen tudjunk táplálkozni, rendelkeznünk kell megfelelő jövedelemmel is, aminek egyik alapfeltétele a pénzügyi intelligencia. Ezért lényegesnek tartottuk, hogy a pénzügyi kultúra és a pénzügyi attitűd fontosabb, számunkra releváns kutatási eredményeit is áttekintsük. A pénz iránti attitűd és bizonyos demográfiai tényezők között szoros kapcsolat mutatható ki. Ez egyik legelterjedtebb pénzügyi attitűdöt mérő skála, a „MAS” (Money Attitude Scale - Pénzügyi Attitűd Skála), mely YAMAUCHI és TEMPLER (1982) nevéhez köthető. A szerzőpáros elsősorban a Freudi és neo-Freudi elméletekre alapozott, mely három alapvető tényezôt feltételezett a pénzügyi attitűddel kapcsolatban, ezek a következők: biztonság, visszatartás és a hatalom-presztízs. Faktoranalízis segítségével, az alábbi öt kategóriából négyet határoztak meg, az ötödik kategória ROBERT és SEPULVEDA (1999) nevéhez füződik.

I. Hatalom-Presztízs: az ide tarozó állítások tartalma szerint a pénz a hatalom és a sikeresség mérőeszköze. Akik ebbe a csoportba tartoznak, úgy vélekednek, hogy pénzzel szinte bármit el lehet érni.

II. Megtartás-Idő: az ide tartozó állítások a pénzügyi tervezésre és a megtakarításokra vonatkoznak. Az ebbe a csoportba tartozóknak fontos a jövő, általában rendelkeznek pénzügyi tervvel.

III. Bizalmatlanság: akik ebben a faktorban magas értékekkel rendelkeznek, bizonytalanok, általában mindenben kételkednek, ami a pénzzel kapcsolatos.

IV. Szorongás: az ide sorolható egyének számára a pénz az idegesség forrása, szorongnak és frusztráltakká válnak, ha a pénzrôl van szó.

V. Minőség: az itt felsorolt tételek a jó minőségű termékekkel vannak összefüggésben. Akik ebben a faktorban mutatnak magas értékeket, rendszerint jó minőségű termékeket vásárolnak. 
A skálát több kutatásban is felhasználták már eredeti és módosított formákban, jelen kutatásban is egy módosított verzió kerül alkalmazásra, mely ANDERSEN és munkatársai (1993) nevéhez füződik. Ök egy úgynevezett „akció-tudatos/megszállott” faktort is kialakítottak. Kutatásunkban a „megtartás-idő”, „szorongás-aggodalom” és „költségtudatosság/ megszállottság” kategóriákat vizsgáltuk.

A jövedelem és a pénz iránti attitűd közötti összefüggés vizsgálata már eddig is sok érdekes eredményt hozott. Vannak kutatások, melyekból az derül ki, hogy a magasabb bérrel rendelkezők szorongóbbak pénzügyeikkel kapcsolatban, ugyanakkor FURNHAM (1984) egyik jelentősebb kutatásából az derül ki, hogy a szorongás inkább az alacsonyabb jövedelemmel rendelkezők körében jellemző. TANG és GILBERT (1995) tanulmányukban megfigyelték, hogy a kevesebb pénzből gazdálkodók, óvatosabban bánnak a pénzükkel. Továbbá, érdekes eredmény az is, hogy a magasabb jövedelemmel rendelkezők számára kényelmet és biztonságot jelent a pénz (WERNIMONT és FITZPATRICK, 1972).

Az Identitás és az egészség kapcsolata. Az „identitás” több tudományágban megjelenő fogalom, ma már nem csak a pszichológiában, szociológiában fordul elő, hanem a közgazdaságtanban is használatos, mint gazdasági folyamatokat magyarázó tényező. Számos identitás létezik, ilyenek például etnikai, nemzeti, nyelvi, vallási, nemi, osztályidentitás stb. Tanulmányunkban elsősorban a szociális identitással foglalkozunk, mivel úgy gondoljuk, hogy ez gyakorol hatást leginkább az egészségre, és a tudatos fogyasztásra. A szociális identitás fogalma Erving Goffman nevéhez köthető, és a következőképpen definiálható: „,...az egyéntôl várt viselkedést nemcsak a társadalmi szerepek befolyásolják, hanem a személyes érték és választások is, ilyen lehet a becsületesség, szépség stb. A legfontosabb kérdés az, hogy az adott személy milyen identitásokat, milyen identitásszerkezetet tart érvényesnek a maga számára" (TÖRÖK, 2010). DOYAL és GOUGH (1991) alapvető célként az ember mindenfajta elnyomás, és kiszolgáltatottság alóli felszabadítását fogalmazza meg, és ennek feltételeit keresi a szükséglet kielégítés nézőpontjából. Az egészségre és az autonómiára alapszükséglet- ként tekintenek; úgy vélekednek, hogy a fizikai és mentális egészség a legalapvetőbb emberi szükségletek, melyek kielégítése elsődleges az egyén számára. Az alapszükségletek másik csoportja az egyéni azonossághoz (identitáshoz), vagy autonómiához kapcsolható. Szerintük ez az alkotó tudat alapszükséglete, az a képesség, mellyel a célokat és a célok eléréséhez szükséges stratégiákat elkészítjük.

$\mathrm{Az}$ identitás kialakulásával ERIKSON (1950a, 1950b) foglalkozott, aki úgy fogalmaz, hogy az identitás az ifjúkor végén alakul ki, amikor a már megszerzett képességek aktiválódnak, és be tudják tölteni a megfelelő szociális szerepeket. BERGER és LUCKMANN (1998:237-239) meghatározása szerint, az egyén identitása az elsődleges szocializációs folyamatban az objektív valóság meghatározott metszetének közvetítésével aktiválódik, és ezt követően már nagyon nehezen módosítható. A folyamatban a társadalmi hatásokat is fontosnak találják: „... a szervezet, az egyéni tudat és a társadalmi struktúra összjátékából termelt identitás reagál a fennálló struktúrára, megőrzi, megváltoztatja, vagy akár újjá formálja... Az identitás típusok- viszont egészükben társadalmi termékek, objektív valóság viszonylag stabil elemei, noha stabilitásuk foka természetesen ismét társadalmilag van meghatározva". Az identitás kialakulásában tehát meghatározó szerepe van a környezetnek is. KRAPPMAN (1980:38) erről így fogalmaz: „csak akkor őrizhető bizonyosan meg az identitás, ha azt mások önkéntes elismerésükkel legitimálják, mivel ebben az esetben nagyobbak lesznek az egyén esélyei arra, hogy a különböző követelmények közötti másokkal „kialkudott” egyensúly megváltozott viszonyok között is helyet kapjon”.

Ahhoz, hogy a társadalomban az identitásunknak megfelelő szerepet be tudjuk tölteni, figyelembe kell venni tehát az egyéni befolyásoló tényezőket, továbbá az intézményi, fizikai, kulturális és gazdasági körülményeket. A megfelelő társadalmi részvételhez szükség van arra, hogy a különböző társadalmi pozíciók elérhetővé váljanak. Az Európai Bizottság finanszírozásával, az Antwerpeni Egyetem közremüködésével megvalósult kutatásban amiben a „referencia” költségvetést elemezték Európában, többek között a nők által betöltött szerepeket és az azokhoz kapcsolódó szükség- 
leteket is vizsgálták. A legfontosabb szerepek a következők voltak:

- anya,

- diák,

- saját vállalkozást/céget vezető személy,

- háztartásbeli,

- valamilyen társulás/szervezet tagja (lehet gazdasági, sport, nemi identitáshoz stb. kapcsolódó),

- független nő,

- feleség,

- állampolgár,

- barát.

Ezen társadalmi pozíciókat a hivatalos társadalmi elvárásoknak és az EU tagállamok nemzetközi irányelveinek megfelelően alakították ki. A kategorizálásnál figyelembe vették továbbá a társadalmi elvárásokat és a nélkülözhetetlen emberi szükségleteket is (STORMS et al., 2014).

A fent vázolt összefüggések mentén, a következő hipotézisek rajzolódtak ki:

H1: A viselkedési szándék és a normatív hiedelmek pozitív összefüggésben állnak a nők egészséges táplálkozásával.

H2: Magasabb jövedelem esetében magasabb szintű a tájékozottság nők körében.

H3a: Azoknak a hölgyeknek, akiknek a táplálkozási szokásait a szúkösség határozza meg, a szorongás/aggodalom és költségvetés tudatosság/megszállottság faktorban erősek.

H3b: A közszférában dolgozó nőkre kevésbé jellemző az egészséges ételek fogyasztása, mint a versenyszférában dolgozókra. (Ennek elsősorban az az oka, hogy az itt dolgozó nőknek sokkal alacsonyabb az átlagkeresete.)

H4: Azon hölgyek, akik magukat leginkább a női szerepeken keresztül identifikálják, azoknak a táplálkozási szokásaikat elsősorban a tudás/a tájékozottság határozza meg.

\section{EMPIRIKUS KUTATÁs - EMPIRICAL RESEARCH}

A kutatásunkban való részvétel önkéntesen történt, a megkérdezés módja az online kérdőív volt - hólabda módszerrel, mely kitöltésére
2017. márciusában került sor. A minta semmilyen értelemben nem tekinthető reprezentatívnak. A kérdőívet összesen 195 hölgy töltötte ki. A kérdőívben többféle kérdés típus megtalálható: egyszerü választás, válaszmátrix, rangsorolás és képhez kapcsolódó rövid válasz. A kérdőív felépítése kérdéscsoportot érintett:

- Az egészségtudatos táplálkozás mozgatórugói - az integrált viselkedési modell ellenőrzése (3.1.);

- Jövedelmi helyzet és az egészségtudatosság kapcsolata (3.2);

- Egészségtudatosság és a pénzügyi tudatosság kapcsolatának vizsgálata (3.3.);

- Identitás és egészségtudatosság kapcsolata (3.4.).

A statisztikai elemzés eredményeit ennek a logikának megfelelően ismertetjük.

\subsection{Az egészségtudatos táplálkozás mozgatórugói - az Integrált Viselkedési Modell ellenőrzése - \\ Drivers of Health Conscious Nutrition \\ - Checking of an Integrated Behavioral Model}

A H1 vizsgálata során az első kérdéskörhöz kapcsolódóan ketté bontottuk a vizsgált populációt azokra, akik többnyire úgy vélik, hogy „egészséges mennyiséget” fogyasztanak a táplálkozáspiramisban megjelölt élelmiszerekből, és azokra, akik úgy vélekedtek, hogy nem. (A 7 elemből öt, vagy annál több elemre igennel válaszolók képezték az első csoportot - 40\%, a többiek pedig a másodikat - 60\%.) Arra voltunk kíváncsiak, hogy vajon milyen demográfiai, és egyéb jellemzőkkel írható le a két csoport, vannak-e markáns szignifikáns különbségek. Megnéztük tehát az életkor, a foglalkozás, a jövedelem és az identitás tekintetében, hogy milyen különbségek vannak. Valamint azt is, hogy a táplálkozási szokásaikat mi határozza meg a két csoportnak.

Az életkor kapcsán nincs markáns eltérés: de az látható, hogy a 26-50 év közöttiek inkább fogyasztanak egészséges mennyiségeket (saját bevallásuk szerint) a különböző élelmiszerekból. A többi változó esetében nem találtunk összefüggést. Az látszik ugyanakkor, hogy az integrált viselkedési modell igazolódik, azaz a motiváció és a viselkedési szándék megléte 
elengedhetetlen, hogy a viselkedési szándék megvalósuljon. A modellből a 2. táblázat elemeit használtuk fel.

Akik jellemzően egyetértettek azzal, hogy az „egészséges életmódot élvezetesnek tartom” (Sig.<0,001); „egészségesen élni kellemes dolog” (Sig.<0,001); „ismeretségi körömben az egészség értéket képvisel” (Sig.<=0,05) és „törekszem arra, hogy egészségesebb életmódot alakítsak ki” (Sig.<0,001), azok a varianciaanalízis szerint, szignifikánsan inkább egészséges mennyiséget fogyasztanak a harvardi piramis elemeiból. Tehát a H1 hipotézis az eredmények alapján elfogadásra került.

Kíváncsiak voltunk arra is, hogy akik egészségesen, vagy általában egészségesen étkeznek (saját bevallásuk szerint), mennyire kritikusak a harvardi kutatási eredmény szülte táplálkozási piramissal szemben. Azt vártuk, hogy akik tudatosak e téren, inkább felülbírálják az általános táplálkozási előírásokat. Statisztikailag igazolható, szignifikáns összefüggést azonban nem találtunk. Véleményünk szerint ez a csoport jobb színben akart feltünni - így egy konkrétabb tudásfelmérés során nem mutatkozna meg a magasabb szintű tájékozottság (ami szükségszerü feltétele az egészséges táplálkozásnak). Érdekes lenne tehát annak vizsgálata, hogy objektíve milyen tudással rendelkeznek a megkérdezettek? (Arra a kérdésre, hogy: „Véleménye szerint egészséges mennyiséget fogyaszt-e különbözó élelmiszerekből?” egyértelműen kiderült, hogy a megkérdezettek nem esznek egészséges adagot a vitaminokból, az olajos magvakból, a babfélékből és a tofuból.

Megvizsgáltuk azt is, hogy a nők saját étkezési szokásának megítélése, összefüggésben van-e azzal a szándékukkal, hogy az egészségmegőrzés érdekében változtassanak. A megkérdezettek 71\%-a állítja, hogy egészségesen étkezik, vagy általában egészségesen étkezik. Akik azt állították, hogy „odafigyelnek arra, hogy egészségesen étkezzenek”, 66\%-ban vál- toztatnának étkezési szokásaikon. Akik úgy válaszoltak, hogy „csak” általában étkeznek egészségesen, 87\%-ban szeretnének változtatni. Akik többnyire nem, vagy határozottan nem étkeznek egészségesen, azoknak hasonló az aránya - 84\%-uk szeretne változtatni az étkezési szokásain. Az eltérések szignifikánsak (Sig.<=0,05).

A kérdőív felvétele során a klasszikus módszertani problémával álltunk szemben: a válaszadó meg akart felelni egy elvárt képnek, amikor azt kérdezzük meg, hogy „Saját meglátása szerint egészségesen étkezik-e?”. Amikor viszont a viselkedési szándékra kérdezünk rá („Gondolt-e már arra, hogy változtat étkezési szokásain...”), a legtöbb megkérdezettnél már nem volt jelen ez a fajta attitüd, és felmerték vállalni a változtatás vágyát. A „Gondolt-e már arra, hogy változtat....” tulajdonképpen ellenőrző kérdésként funkcionált ez esetben. A kutatás alapján egyértelműen megállapítható, hogy az egészségmegőrzés érdekében a megkérdezettek 79,3\%-a változtatna az étkezési szokásain. Ez összecseng a korábbi kutatási eredményekkel. Fontos volt számunkra annak megválaszolása is, hogy vajon a változtatási szándék mögött mi áll? Azt feltételeztük, hogy aki változtatna az étkezési szokásain, annak többnyire súlyos egészségügyi problémája van (155 fó úgy nyilatkozott, hogy nincs súlyos egészségügyi problémája, és csupán a megkérdezettek 20,1\%-a, azaz 39 fó nyilatkozott úgy, hogy szenved valamilyen betegségben.) Megvizsgáltuk tehát $\mathrm{Chi}^{2}$ próbával a két kérdés kereszttábláját. A kutatókat is meglepve gyakorlatilag ugyanaz az arány jött ki. Akik tehát változtatnának, azoknak 20\%-a küzd súlyos egészségügyi problémával, és akik nem, azoknál szintén 20\% ez az arány. A betegségek és a táplálkozási szokások között a megkérdezettek tehát nem vélelmeznek erős összefüggést. 


\section{Az Integrált Viselkedési Modellból felhasznált elemek} (Items Used in the Integrated Behavioral Model)

\begin{tabular}{|c|c|c|c|c|}
\hline $\begin{array}{l}\text { Attitűd/tapasztalati } \\
\text { attitűd (Attitude/ } \\
\text { empirical attitudes) }\end{array}$ & $\begin{array}{l}\text { Viselkedési szándék } \\
\text { (Intent Behavior) }\end{array}$ & $\begin{array}{l}\text { Észlelt normák/ } \\
\text { rendelkező norma } \\
\text { (Detected norms/ } \\
\text { standard norm) }\end{array}$ & $\begin{array}{l}\text { Észlelt normák/ leíró } \\
\text { norma (Detected } \\
\text { norms/descriptive } \\
\text { standard) }\end{array}$ & $\begin{array}{l}\text { Normák fontossá- } \\
\text { ga (Importance of } \\
\text { norms) }\end{array}$ \\
\hline $\begin{array}{l}\text { Az egészséges élet- } \\
\text { módot élvezetesnek } \\
\text { tartom (I find healthy } \\
\text { lifestyle fun) }\end{array}$ & $\begin{array}{l}\text { Vágyom rá, hogy } \\
\text { egészségesebben } \\
\text { éljek (I want to be } \\
\text { healthier) }\end{array}$ & $\begin{array}{l}\text { Az ismeretségi } \\
\text { körömben az egészség } \\
\text { értéket képvisel (In } \\
\text { my acquaintance, } \\
\text { health is a value) }\end{array}$ & $\begin{array}{l}\text { Az ismerőseim sokat } \\
\text { tesznek az egészségü- } \\
\text { kért (My } \\
\text { acquaintances do a } \\
\text { lot for their health) }\end{array}$ & $\begin{array}{l}\text { Nem foglalkoztat, } \\
\text { hogy mit gondolnak } \\
\text { rólam (I do not care } \\
\text { what they think of } \\
\text { me) }\end{array}$ \\
\hline $\begin{array}{l}\text { Egészségesen élni } \\
\text { kellemes dolog (To } \\
\text { live healthily is a } \\
\text { pleasant thing) }\end{array}$ & $\begin{array}{l}\text { Törekszem arra, } \\
\text { hogy egészségesebb } \\
\text { életmódot alakítsak } \\
\text { ki (I strive to shape a } \\
\text { healthier lifestyle) }\end{array}$ & & $\begin{array}{l}\text { A legtöbb ember so- } \\
\text { kat tesz az egészségé- } \\
\text { ért (Most people do a } \\
\text { lot for their health) }\end{array}$ & \\
\hline
\end{tabular}

Forrás (Source): Saját kutatás (Own research)

\subsection{Jövedelmi helyzet és az egészségtudatosság kapcsolata - The Relationship between Income Status and Health Consciousness}

A H2 hipotézishez kapcsolódó legfontosabb kérdésünk az volt, hogy mi határozza meg elsősorban a táplálkozási szokásokat? A táplálkozási szokásokat meghatározó tényezők tekintetében a tájékozottság (tudás) volt a leginkább meghatározó (a minta 36\%-a válaszolt így). Azoknak, akiknek a táplálkozási szokásait leginkább az anyagi helyzete határozza meg, a minta 17\%-át képezi. Mindössze 10\% válaszolt úgy, hogy a táplálkozása során elsősorban szokás alapú döntéseket hoz. A kitöltők mindöszszesen 5\%-át tették ki azok, akik pedig a márkahüségre fektetik a legnagyobb hangsúlyt.

Különválasztottuk azokat a hölgyeket, akik azt mondták, hogy általában vagy leginkább meghatározó a táplálkozási szokásaik tekintetében a tájékozottság, és a tudás, azoktól, akiknél ez kevésbé vagy legkevésbé jellemző. S ennek megfelelően azonosítottuk, hogy milyen tulajdonságokkal rendelkezik a két csoport. Várakozásaink szerint, azoknak a hölgyeknek magasabb a tudása ezen a területen, akik magasabb jövedelemmel rendelkeznek. Ók a táplálkozási szokásaikat aszerint tudják alakítani, hogy mi az, ami jó nekik. Eredményeink szerint, a 250 ooo Ft feletti jövedelemmel rendelkezők 78\%-a válaszolt úgy, hogy táplálkozási szokásait a tudása, illetve tájékozott- sága határozza meg általában vagy leginkább (Sig.<=0,05). Akik 350 ooo Ft felett keresnek, ott még magasabb ez az arány, 83\%. Látható tehát, hogy a jövedelem növekedésével, mind meghatározóbb szerephez jut a tájékozottság, és a tudás a táplálkozási szokások esetében. A H2 hipotézis tehát az eredményeink alapján megerősítést nyert. (H2: Magasabb jövedelem esetében magasabb szintű a tájékozottság nők körében.)

Életkor tekintetében nem találtunk szignifikáns összefüggést. A kutatási eredményeink ugyancsak nem bizonyítják, hogy a magasabb jövedelmi viszonyok egészségesebb táplálkozási szokásokat eredményezne. Elsősorban azért, mert az általános egészségi állapotra nem kérdeztünk rá, csak arra, hogy van-e súlyos egészségügyi problémája. Így tehát lehetetlen volt egy erre vonatkozó statisztikai elemzés. A súlyos egészségügyi problémák esetében az látható, hogy ez nem köthető demográfiailag jól leírható csoportokhoz.

Ugyanakkor érdekes összefüggések rajzolódtak ki a tekintetben, hogy milyen jellemző IBM és pénzügyi attitűd kapcsolódósások vannak. A következő részben kizárólag a szignifikáns összefüggéseket tételezzük. Az IBM esetében „Az egészséges életmódot élvezetesnek tartom” elem Sig.<0,001; az „Egészségesen élni kellemes dolog" elem Sig. $<=0,05$; „Az ismeretségi körömben az egészség értéket képvisel” tényező Sig.<0,001 és a „Törekszem arra, hogy egészségesebb életmódot alakítsak 
ki” elem Sig.<0,001 szinteket mutatnak. Tehát egyértelmú, hogy ezekben az itemekben a tájékozottabbak, erősebben egyetértettek ezekkel az állításokkal. Érdekes összefüggés, hogy aki tudás alapú táplálkozási szokásokat alakít ki, az mindezt élvezi is. Valószínúleg érvényesül az a pszichológiai összefüggés, hogy minél több energiát teszünk bele valamibe, annál magasabbra értékeljük annak eredményét, minőségét.

\subsection{Egészségtudatosság és a pénzügyi tudatosság kapcsolatának vizsgálata - Examination of the Relationship between Health Consciousness and Financial Awareness}

A H3 hipotézist két szempontból közelítettük meg. A pénzügyi attitűdöt mérő állítások és a tájékozottság között semmilyen szignifikáns összefüggést nem találtunk azoknál, akik a szokásaikat a tudásuk, és a tájékozottságuk alapján alakítják ki. Ami bizonyos értelemben meglepő, hiszen azt vártuk, hogy aki a pénzügyek terén magasabb tudatossággal rendelkezik, az élet más szféráiban is magas szintü tudatosságot tanúsít. Ezt a fajta generalizációt a mi kutatásunk nem igazolja. Ugyanakkor, amikor azt a csoportot vizsgáltuk, akinek a táplálkozási szokásait az anyagi helyzete határozza meg „általában vagy leginkább” a várakozásainknak megfelelő összefüggések rajzolódtak ki. Nekik alacsonyabb a jövedelmük (akik 150 ooo Ft alatt keresnek, azoknak 64\%-a állítja, hogy, az anyagi helyzete határozza meg általában vagy leginkább a táplálkozási szokásait, míg a 250000 Ft feletti keresetúek ugyanezen aránya csak 19\%) ezért nem meglepő, hogy kevésbé tudnak egészségesen élni. „A vágyom rá, hogy egészségesebben éljek" elem esetében szignifikánsan (Sig.<=0,05) magasabb értékek mutatkoznak. Magasabb értékek látszódnak a „szorongás, aggodalom” és a „költségvetés tudatosság/ megszállottság" dimenziókban. A következő elemeknél pedig kiváltképp erős szignifikáns összefüggések érvényesültek: „Rendszeresen vadászom az akciókat” (Sig.<0,001); „Gondterhelt vagyok, ha a pénzről van szó” (Sig.<0,001); „Sokszor automatikusan gondolom, hogy valamit nem engedhetek meg magamnak, még akkor is, ha ez nem igaz” (Sig.<=0,05); „Boszszús vagyok, ha lemaradok egy leárazásról" (Sig.<0,05); „Zavar, amikor felfedezem, hogy valamit olcsóbban is megvehettem volna" (Sig.<0,05). Egyértelmű tehát, hogy akiknek a táplálkozási szokásait a szúkösség határozza meg, a szorongás/aggodalom és költségvetés tudatosság/megszállottság faktorokban erősek.

A H3 hipotézis további vizsgálatainál a következő összefüggéseket kaptuk. A jövedelem forrását tekintve a közszféra és versenyszféra válaszadóit különítettük el. A közszférában dolgozók körében 64\%, a versenyszférában 74\% válaszolta azt, hogy a tudás és tájékozottság határozza meg leginkább a táplálkozási szokásait. Szignifikáns összefüggés azonban nem mutatható ki. Ugyanakkor, ha az anyagi helyzet táplálkozási szokásokra gyakorolt hatását vizsgáljuk, akkor a közszférában 59\%, a versenyszférában pedig $42 \%$ válaszolt úgy, hogy ez leginkább meghatározó szempont (Sig.<0,05).

„A közszférában dolgozó nőkre kevésbé jellemző az egészséges ételek fogyasztása, mint a versenyszférában dolgozókra." Hipotézis kapcsán, a Chi ${ }^{2}$ próba eredménye alapján megállapítható, hogy van szignifikáns összefüggés a változók között, ezért, ez a hipotézis elfogadható (Sig.<0,05). A versenyszférában dolgozók 60,2\%-a vélekedik úgy, hogy egészségesen étkezik, míg a közszférában dolgozók csupán 39,8\%-a ítéli úgy, hogy egészségesen táplálkozik. Itt is kirajzolódik az az összefüggés, miszerint a versenyszférában dolgozók jobban keresnek, mint a közszférában dolgozók. A mintában előbbiek 44\%-a keres 250 ooo Ft felett, a közszférában dolgozók pedig csak 29\%-a. Megvizsgáltuk, hogy a jövedelem forrása hogyan hat a táplálkozási szokásokra. Szignifikáns különbséget találtunk az anyagi helyzet hatását tekintve. A közszféra esetében a megkérdezettek 59\%-a jelölte meg, hogy táplálkozási szokásait az anyagi helyzete határozza meg általában, vagy leginkább. Míg a versenyszférában ez csak 47\%. Tehát itt is igazolódik az az összefüggés, hogy aki jobban keres, az inkább tudás alapú döntéseket hoz a mindennapokban, s ennek eredményeképpen egészségesebb táplálkoznak. 


\subsection{Az identitás és egészségtudatosság kapcsolata - The Relationship between Identity and Health Consciousness}

A H4 hipotézis értékelését a következők során mutatjuk be. Kutatásunk egyik fontos kiindulópontja volt, hogy az egyén identitása markánsan befolyásolja, hogy milyen egészségtudatossággal rendelkezik, s ennek megfelelően hogyan alakítja ki a táplálkozási szokásait. Kérdőívünk erre vonatkozó kérdése azonban túl komplexnek bizonyult, így a statisztikai értékelés szempontjából kevés értékelhető válasz érkezett be. Ennek megfelelően a H4-es hipotézissel kapcsolatban semmilyen szignifikáns összefüggés nem volt kimutatható. Azaz a beazonosított identitáskategóriák (anya, vezető, feleség, diák stb.) az egészségtudatosság területén nem mutattak markáns eltéréseket.

\section{4. ÖSSZEFOGLALÁS - SUMMARY}

Tanulmányunk központi feltevése volt, hogy Magyarországon az anyagi helyzet, a tudatosság szintje, valamint az „identitás” döntő módon befolyásolja azt, hogy ki vállalja az egészséges táplálkozáson alapuló életmódot. Az egészségtudatosság és a pénzügyi attitűd között is vélelmeztünk összefüggést, valamint az egészségtudatosság a viselkedési szándék és a normatív hiedelmek között is pozitív kapcsolatot feltételeztünk. Kutatásaink megerősítik: A tapasztalati attitűd, a viselkedési szándék és a környezetben észlelt normák szoros kapcsolatban vannak azzal, hogy egészségesen táplálkozik-e az egyén. Várakozásaink szerint azoknak a hölgyeknek határozza meg elsősorban a tudása és a tájékozottsága a táplálkozási szokásait, akik magasabb jövedelemmel rendelkeznek. A kutatásunk igazolta: a jövedelem növekedésével, mind meghatározóbb szerephez jut a tájékozottság és a tudás. A jövedelem tehát sorsdöntő abból a szempontból, hogy képes-e valaki Magyarországon egészségesen táplálkozni - ez ugyanis sokkal drágább és időigényesebb, mint a rutinszerü, nem átgondolt étkezés. Akiknek a táplálkozási szokásait saját bevallása szerint az anyagi helyzete határozza meg leginkább (és nem a tájékozottság/tudás, vagy a márkahüség) - az átlag alatti jövedelem kategóriába esnek. Ez a csoport szorongóbb a pénzügyek területén, jellemző rájuk a költségvetés tudatosság, és az akcióvadászat is.

\section{IRODALOMJEGYZÉK - REFERENCES}

Andersen, J. - Camp, P. - Kiss, E. Wakita, S. - Weyeneth, J.: The Money Attitude Scale: What College Students Think About the Green Stuff. Proceedings of the American Council on Consumer. Interests. 1993. 39 377-384.

Berger, P. L. - Luckmann, T.: A valóság társadalmi felépítése. Jószöveg Mühely Kiadó, Budapest, 1998.

Doyal, L. - Gough, I.: A Theory of Human Need. Guilford, New York, 1991.

Dudás, R.: A táplálkozás. Változó Világ. 36. Press Publica, Budapest, 1998.

Erikson, E. H.: Childhood and Society. In: Erikson, E. H. (szerk): Kindheit und Gesellschaft. Stuttgart Klett, Frankfurt, $1950 a$.

Erikson, E. H.: Growth and Crisis of the „Healthy Personality” 55-122. In: Erikson, E. H. (szerk.): Identität und Lebenscyklus. Frankfurt A. M: Suhrkamp, 1950b.

Furnham, A.: Many Sides to the Coins, the Psychology of Money Usage. Personality and Individual Differences. 1984. 5 (5) 501-509.

Krappman, L.: Az identitás szociológiai dimenziói. Oktatási Minisztérium, Budapest, 1980.

KSH: Társadalmi helyzetkép 2010. In: Központi Statisztikai Hivatal. URL: https://www.ksh.hu/docs/hun/xftp/ idoszaki/thk/thk10_egeszseg.pdf (Letöltés dátuma: 2017. febr. 25.)

KSH: Európai lakossági egészségfelmérés, 2009. In: Központi Statisztikai Hivatal. URL: http://www.ksh.hu/apps/shop. kiadvany?p_kiadvany_id=79467\&p_ lang=HU (Letöltés dátuma: 2017. febr. 26.) 
Lajos, A.: $\quad A z \quad$ egészségtudatosság sajátos vonásai a 14-18 éves korosztályban, különös tekintettel az élelmiszerfogyasztásra. Doktori Értekezés. 2005. URL https://szie.hu/ file/tti/archivum/Lajos_Attila_ertekezes. pdf (Letöltés dátuma: 2017. febr. 27.)

Medical Online.: Fókuszban az egészségtudatosság: merre tartunk? URL: http://medicalonline.hu/cikk/fokuszban az_egeszsegtudatossag__merre_tartunk_ 2010. (Letöltés dátuma: 2017. febr. 26.)

Montano, D. E. - Kasprzyk, D.: Theory of Reasoned Action, Theory of Planned Behavior, and the Integrated Behavioral Model. 2008. In: Glanz, K. - Rimer, B. K. -Viswanath, K. (szerk.): Health behavior and health education: Theory, research, and practice. San Francisco, CA, US: Jossey-Bass, 67-96.

OGYÉI: OTÁP 2014. URL: https://www.ogyei. gov.hu/otap_2014/ (Letöltés dátuma: 2017. febr. 27.)

Roberts, J. - Sepulveda, C. J.: Demographics and Money Attitudes: A Test of Yamauchi and Templer's Money Attitude Scale in Mexico. Personality and Individual Differences. 1999. 27 (1) 19-35.

Rodler, I.: Táplálkozási ajánlások a magyarországi felnött lakosság számára. 2004. URL: http://www.fao.org/3/aas6840.pdf. (Letöltés dátuma: 2017. febr. 27.)

Róna, P. - Rácz, J. - Rózsa, A. - Szepesi, A. - Törő́csik, M. - Kató, G. - Repa, I.: A paradigmaváltás alapjai. Egészségügyi gazdasági szemle. 2010. 145-48.

Storms, B. - Goedemé, T. - Van den Bosch, K. - Penne, T. - Schuerman, N. - Stockman, S.: Review of Current State of Play on Reference Budget Practices at National, Regional, and Local Level. Pilot Project for the Development of a Common Methodology on Reference Budgets In Europe. Contract no. VC/2013/0554. Brussels: European Commission, Brussels.
Szabó, S.: Egészségorientált táplálkozási szokások és a fogyasztói magatartás kapcsolata. Doktori (PhD) értekezés URL: http://www.gtk.ke.hu/tartalom/doktori/ Szabo-Sara-doktori-ertekezes.pdf. 2016. (Letöltés dátuma: 2017. jan. 28.)

Szinapszis: Az orvosok szerint javult a betegek egészséggel kapcsolatos attitüdje az elmúlt 5 évben. http://www.szinapszis. $\mathrm{hu} / \mathrm{hu} /$ hirek/az-orvosok-szerint-javult-abetegek-egeszseggel-kapcsolatos-attitdjeaz-elmelt-5-evben. 2016. URL: (Letöltés dátuma: 2017. febr. 26.)

Tang, T. L. P. - Gilbert, P. R.: Attitudes Toward Money as Related to Intrinsic and Extrinsic Job Satisfaction, Stress and Work-Related Attitudes. Personality and Individual Differences. 1995. 19 (3) 327332.

Török, Cs.: Identitástudat és egyenruha - Az Egyesült Államok, Franciaország és Magyarország mai katonai egyenruháinak interkulturális összehasonlítása. URL: http://elib.kkf. hu/edip/D_15187.pdf 2010 (Letöltés dátuma: 2017. jan. 28.)

Törőcsik, M.: Fogyasztói magatartás. Akadémiai Kiadó, Budapest, 2011.

Vetőné Mózner, Zs.: Az élelmiszerfogyasztás szerkezete és környezeti hatása Magyarországon. 2014. URL: http:// unipub.lib.uni-corvinus.hu/1754/1/o8_ Vetone_Mozner_Zsofia.pdf (Letöltés dátuma: 2017. ápr. 28.)

Yamauchi, K. T. - Templer, D. L.: The development of money attitude scale. Journal of Personality Assessment. 1982. 46 (may) 522-528.

Walter, W. C. - Skerrett, P. J.: Eat, Drink, and Be Healthy: The Harvard Medical School Guide to Healthy Eating. Free Press, New York, 2005.

Wernimount, P. - Fitzpatrick, S.: The Meaning of Money. Journal of Applied Psychology. 1972. 56 218-226. 